\title{
Hazards due to polycyclic aromatic hydrocarbons (PAHs) and heavy metals at the closed Kubang Badak landfill, Selangor
}

\author{
Nor Amani Filzah Mohd Kamil ${ }^{1,2}$, Suhaimi Abdul-Talib ${ }^{2}$ \\ ${ }^{1}$ Faculty of Civil and Environmental Engineering, Universiti Tun Hussein Onn Malaysia, 86400 BatuPahat, Johor. Malaysia \\ ${ }^{2}$ Faculty of Civil Engineering, Universiti Teknologi MARA, 40450 Shah Alam, Selangor, Malaysia
}

Email address:

noramani@uthm.edu.my(N. A. F. M.Kamil), ecsuhaimi@salam.uitm.edu.my(S. A. Talib)

\section{To cite this article:}

Nor Amani Filzah Mohd Kamil, Suhaimi Abdul-Talib. Hazards Due to Polycyclic Aromatic Hydrocarbons (PAHs) and Heavy Metals at the Closed Kubang Badak Landfill, Selangor. International Journal of Environmental Monitoring and Analysis. Vol. 1, No. 2, 2013, pp. 71-77. doi: 10.11648/j.ijema.20130102.16

\begin{abstract}
Demand on redevelopment of a closed landfill is increasing due to limited land resources. However, the hazards of a closed landfill remain unknown. Thus, there is a need to assess the health hazard for a closed landfill to ensure its suitability for future development. The aim of this study is to evaluate the distributions and hazards based on soil samples taken from a closed landfill located at Kubang Badak, Selangor, with specific focus on Polycyclic Aromatic Hydrocarbons (PAHs) and heavy metals. A total of ten soil samples were collected using hand auger. PAHs were extracted using Microwave Assisted Extraction (MAE) and analysed using Gas Chromatography-Mass Spectrometer, while heavy metals were digested with MAE and analysed using Inductively Coupled Plasma. Concentrations of PAHs were compared to guidelines from Canada, Netherlands and Denmark. Concentrations of heavy metals were compared to guidelines from United Kindom.. Results showed that 12 PAHs compounds were distributed consistently except for phenanthrene and anthracene. Most abundant was phenanthrene with an average value of $62.02 \mu \mathrm{g} / \mathrm{kg}$. For heavy metals, $\mathrm{Zn}$ was found the most abundant ranging from $256.9-666.05 \mathrm{mg} / \mathrm{kg}$. This is followed by $\mathrm{Mn}(29.05-262.5 \mathrm{mg} / \mathrm{kg}), \mathrm{V}(3.85-174.65 \mathrm{mg} / \mathrm{kg}), \mathrm{Ga}$ (34.4-182 mg/kg), Rb (63.7-135.8 mg/kg), Cr (37.8-136.85 mg/kg), Sr (0-158.2 mg/kg), Mg (16.1-173.6 mg/kg), Cu (0$201.6 \mathrm{mg} / \mathrm{kg})$ and $\mathrm{Pb}(0.7-89.25 \mathrm{mg} / \mathrm{kg})$. Two heavy metals, i.e. $\mathrm{Cr}$ and As were found to have concentrations above concentration limits permissible for residential activities. Whilst PAHs compounds were distributed uniformly, heavy metals were not. Based on the findings, landfill area is not suitable for residential area development as concentrations of $\mathrm{Cr}$ and As are above permissible limits.
\end{abstract}

Keywords: Closed Landfill, Heavy Metals, Health Hazard, Pahs, Soil Contamination

\section{Introduction}

Partially degraded municipal waste is associated with both organic and inorganic waste. Organic waste includes polycyclic aromatic hydrocarbon (PAHs), Polychlorinated Biphenyls (PCB), Polychlorinated Dibenzo-p-dioxins (PCDD) and Polychlorinated Dibenzofurans (PCDF). Inorganic wastes includes heavy metals, nitrogen, nitrate, ammonia, phosphorous and phosphate. These pollutants originate from waste materials such as oils, pesticides, discarded electronic equipment, debris waste, used paints, organic waste, etc. These wastes must be properly managed to minimize their impacts on the environment and human health. In Malaysia, these wastes are mostly dumped into landfill area [1]. Dumping activities at landfills make it a major reservoir and sink for pollutants because of the high soil holding capacity. In addition, soil also has the capability to accumulate the pollutants. Soil is considered as a good indicator of pollution and environmental hazard [2].

Land used for waste disposal may be contaminated. Its redevelopment often requires that unacceptable risks are assessed and managed so that the site becomes suitable for its new use. One of the major criteria to be fulfilled before such land can be re used is to ensure that pollutant levels are within the clean-up guidelines. This is to ensure that the site is safe with no health hazard to human and the environment. 
Micropollutants such as PAHs and heavy metals are considered among the most adverse pollutants. PAHs are ubiquitous contaminants and highly toxic, mutagenic and carcinogenic that can be linked to other health problem which had attracted the interest of the research community $[3,4]$. Sixteen PAHs compound have been identified by USEPA as priority pollutant. They represent the most adverse effects that are caused be anthropogenic activities [5]. Ingestion, inhalation and skin contact of heavy metals on humans can cause disturbance to biological reactions, long lasting harm to vital organs or even death [6].

Therefore, the investigation of soil pollutants at closed landfill is needed to ensure the landfill is safe for its future development and subsequent uses. Thus, the objective of this study was to evaluate the distributions and health hazards of soil samples from a closed landfill located at Kubang Badak, Selangor, with focusing on PAHs and heavy metals.

\section{Experimental}

\subsection{Sampling Site}

Kubang Badak landfill in Batang Berjuntai, Selangor is located in the midwestern part of the Malaysian Peninsular. The site was properly closed by the authority on 7th April 2007 and was replaced with Bukit Tagar sanitary landfill, which is located near the site. The closed landfill site covered an area of 1 hectare. The servive area for the Kubang Badak landfill extend from Tanjong Karang to Sepang covering more than $70 \%$ of Selangor state [7]. A large number of steel related industries, cement industries, wood industries are located in the servive area. In addition, there are also residential areas and a university (UNISEL) located in the area [8]. The closed landfill is located next to Sungai Selangor. Leachate produced from the site can easily pollute the river. The sampling sites were chosen so as to represent the pollution distribution on the site.

Soil samples were collected from ten locations during the period of November 2009. For each location, duplicate samples were collected from approximately $1 \mathrm{~m} 2$ areas. Sampling points are shown in Figure 1 and details of these sampling locations are provided in Table 1.

Table 1. Description of sampling station at Kubang Badak landfill

\begin{tabular}{ll}
\hline Sampling Station & Description \\
\hline S1 & Upper level, covered with thick layer of soil, \\
near to mobile flare \\
S2 to S6 & Upper level, covered with thick layer of soil \\
S7 & Lower level, covered with thin layer of soil \\
S8 to S9 & Middle of upper and lower level, covered with \\
S10 & soil \\
\hline
\end{tabular}

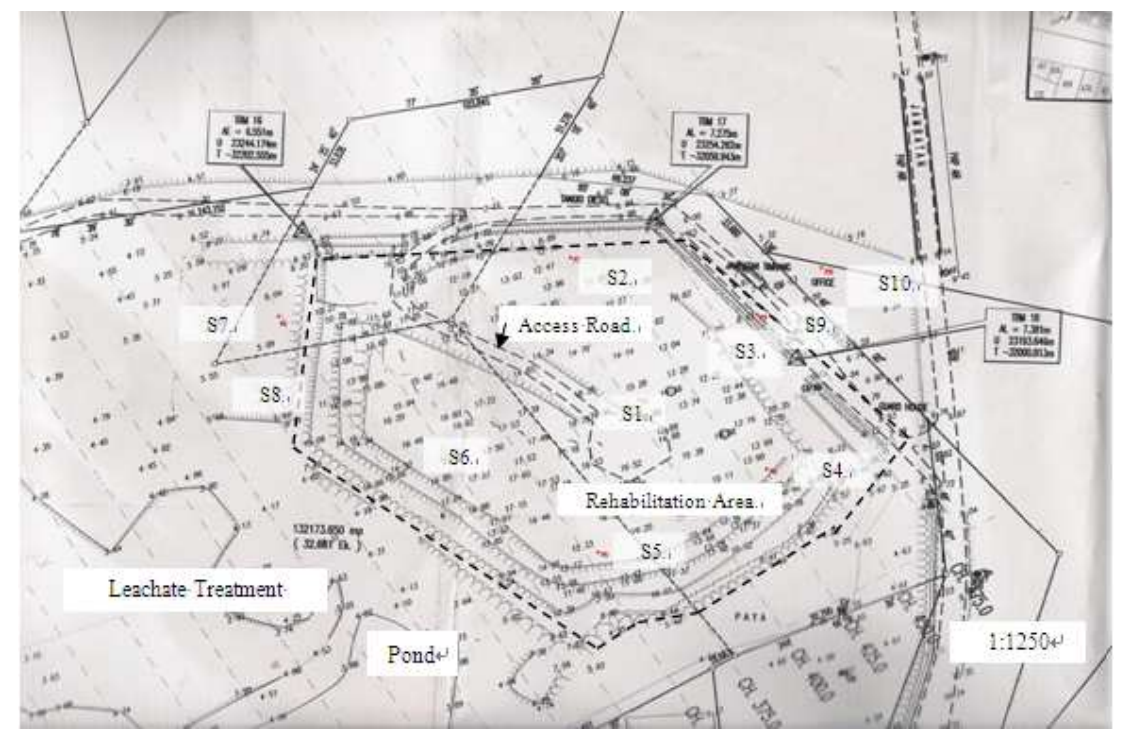

Figure 1. Location map of the sampling stations in Kubang Badak landfill.

\subsection{Sampling Site and Preparation}

Landfill soil samples were collected using a hand auger at depths of $1 \mathrm{~m}$ and kept in high-density polyethylene (HDPE) plastic bag. All samples were transported to laboratory in an icebox to minimize sample degradation and to avoid loss of PAHs through volatilisation. In preparation for analysis, samples were air dried at room temperature and sieved to collect particles less a $1 \mathrm{~mm}$. The selected size of particles was based on [9], which reported that PAHs are more abundant in finer particles. The particles were stored in plastic bags and sealed, homogenized and kept in this manner until ready for analysis.

\subsection{PAHs Extraction and Analysis}

For sample analysis, $500 \mathrm{mg}$ of the contaminated sand sample was dissolved in $25 \mathrm{ml}$ of n-hexane and acetone 7:3 
$(\mathrm{v} / \mathrm{v})$. The extractions were performed with the pressurized microwave extraction system (MAE) Multiwave 3000 (Rotor 8XF100 SOLV and solvent safety system under controlled pressure for a specified time. Extraction process was done within 40 minutes under a pressure of 10 bars. When the extraction period was completed, the equipment was allowed to cool down to room temperature for 20 minutes. Subsequently, the samples were filtered with Whatman glass fibre filters with pore size of $11 \mu \mathrm{m}$ and kept in $25 \mathrm{ml}$ universal bottles. The samples were concentrated by means of a rotary evaporator to about $1 \mathrm{ml}$.

PAHs concentrations were measured using Gas Chromatography Mass Spectrometer (Perkin Elmer Clarus 600 ), equipped with Elite Column 5MS with $30 \mathrm{~m}$ long $\mathrm{X}$ $0.25 \mathrm{~mm}$ internal dimension $\mathrm{X} 0.25 \mu \mathrm{m}$ thickness. The injector was operated at $250 \mathrm{oC}$ in the splitless mode with a 3 minute splitless period. Helium was used as the carrier gas with $1 \mathrm{ml} / \mathrm{min}$ constant flow rate. The column temperature was initially set at $50 \mathrm{oC}$ for $1 \mathrm{~min}$, increased to $250 \mathrm{oC}$ at a rate of $25 \mathrm{oC} / \mathrm{min}$ and then kept constant at 30 minutes. The total run for each sample is set to 54 minutes.

\subsection{Heavy Metals Digestion and Analysis}

$100 \mathrm{mg}$ of landfill soil was digested with $2 \mathrm{ml}$ of $\mathrm{HNO} 3$ (65\%), $1 \mathrm{ml} \mathrm{HCl} \mathrm{(37 \% ),} \mathrm{0.5ml} \mathrm{HF} \mathrm{(40 \% )} \mathrm{and} \mathrm{0.5ml} \mathrm{H3PO4}$ $(85 \%)$. Digestion was performed with the pressurized microwave extraction s ystem (MAE) Multiwave 3000 (Rotor 8XF100 SOLV and solvent safety system) controlled power for a specified time as shows in Table 2 . Temperature and pressure reaction conditions were set to $218^{\circ} \mathrm{C}$ and 30 bars, respectively. The resulting solution was transferred into measuring flask to a volume of $70 \mathrm{~mL}$. Subsequently, the samples were filtered with Whatman glass fibre filters with pore size of $0.45 \mu \mathrm{m}$. For $5 \mathrm{ml}$ final digestion, $100 \mu \mathrm{L}$ of internal standards, i.e., $2 \mathrm{ppm}$ Sc was added.

Table 2. Multiwave Program for Heavy Metals Digestion

\begin{tabular}{lll}
\hline Power $(\mathrm{W})$ & Time $(\mathrm{min})$ & Fan \\
\hline 400 & 6 & 0 \\
1000 & 20 & 0 \\
0 & 15 & 3 \\
\hline
\end{tabular}

Table 4. Concentration limit ( $\mathrm{mg} / \mathrm{kg}$ ) for Heavy Metals.

\begin{tabular}{llllll}
\hline HM & As & Pb & Cu & Cr & Zn \\
\hline CLEA $^{\mathbf{a}}$ & 20 & 450 & NA & 130 & NA \\
CLEA $^{\mathbf{b}}$ & NA & 750 & NA & 5000 & NA \\
\hline
\end{tabular}

${ }^{\mathrm{a}}$ Residential ${ }^{\mathrm{b}}$ Commercial and Industrial

Heavy metals concentration was measured by Inductively Coupled Plasma-Optical Emission Spectrometry (ICP-OES, Perkin Elmer Optima 7000). The calibration of the instrument for each metal was performed according to its wavelength and standard solutions. Multi heavy metals standard solutions were prepared at $0.01 \mathrm{ppm}$, $0.1 \mathrm{ppm}, 1 \mathrm{ppm}$ and $10 \mathrm{ppm}$.

\subsection{Comparison with Health Hazard Guidelines}

Health hazard guideline values for PAHs in soil from three countries are shows in Table 3. These guidelines provides useful indicator values for the purpose of estimating the potential hazard to human health $[10,11,12]$. Health hazard guideline for heavy metals in soil as stipulated in United Kingdom [13] is shown in Table 4, which covers three categories, i.e., residential, commercial and industry [13].

Table 3. Soil Quality Criteria $(\mu \mathrm{g} / \mathrm{kg})$ for PAHs from Netherlands, Denmark and Canada

\begin{tabular}{|c|c|c|c|c|c|c|c|c|c|c|c|c|c|}
\hline Country & $\mathrm{Na}$ & $\mathbf{P h}$ & An & Fl & Py & $\mathbf{B a A}$ & $\mathrm{Ch}$ & Bkf & BaP & IP & DaH & BgP & PAHs (sum) \\
\hline Canada & 600 & 5000 & NA & & 10000 & 1000 & NA & 1000 & 700 & 1000 & 1000 & NA & NA \\
\hline Netherlands & NA & & & & & & & & 100 & NA & 100 & NA & $1500^{\mathrm{a}}$ \\
\hline Denmark & NA & & & & & & & & & & & & $1000^{b}$ \\
\hline
\end{tabular}

${ }^{a}$ Sum of 5 PAHs: Fluotherene, Benzo(b+k)fluoranthene, Benzo(a)pyrene, Dibenz(a,h)anthracene, Indeno(1,2,3-cd)pyrene.

${ }^{b}$ Sum of 10 PAHs: Napthalene, Phenanthrene, Anthracene, Fluoranthene, Benz(a)anthracene, Chrysene, Benzo(b+k)fluoranthene, Benzo(a)pyrene, Indeno(1,2,3-cd)pyrene, Benzo[ghi]perylene.

Table 5. Concentration of PAHs in Kubang Badak landfill ( $\mu \mathrm{g} / \mathrm{kg})$

\begin{tabular}{lllllllllllll}
\hline PAHs & Na & Flu & Ac & Ph & An & Fl & Py & BaA & Tr & BjF & BaP & BgP \\
\hline AVE & 16.41 & 15.04 & 15.33 & 62.02 & 23.01 & 15.70 & 15.53 & 16.53 & 15.59 & 16.30 & 16.50 & 19.98 \\
STDEV & 0.054 & 0.160 & 0.004 & 43.159 & 9.182 & 0.040 & 0.266 & 0.006 & 0.054 & 0.009 & 0.009 & 0.021 \\
MIN & 16.34 & 14.95 & 15.32 & 15.64 & 16.29 & 15.66 & 15.24 & 16.52 & 15.56 & 16.29 & 16.4 & 19.96 \\
MAX & 16.51 & 15.48 & 15.33 & 121.5 & 43.92 & 15.79 & 15.83 & 16.54 & 15.73 & 16.32 & 16.52 & 20.02 \\
\hline
\end{tabular}

Na: Napthalene, Ph: Phenanthrene, An: Anthracene, Fl: Fluoranthene, Py: Pyrene, BaA: Benz(a)anthracene, Ch: Chrysene, BkF: Benzo(b+k)fluoranthene, BaP: Benzo(a)pyrene, IP: Indeno(1,2,3-cd)pyrene, DaH: Dibenz(a,h)anthracene, BgP: Benzo[ghi]perylene

\section{Result and Discussion}

\subsection{Distribution of PAHs Concentration}

Based on this study, twelve PAHs were found to be present in the samples. These PAHs were 2-3 rings, i.e. naphthalene, fluorene, acenaphthene, phenanthrene and anthracene, 4-5 rings, i.e. fluoranthene, pyrene, benz(a)anthracene, triphenylene, benzo(j)fluoranthene, benzo(a)pyrene and 6 rings, i.e. Benzo(g,h,i)perylene. Tables 5 shows that all the PAHs compounds detected were 
distributed consistently except for phenanthrene (stdev: 43.16) and anthracene (stdev: 9.18).

For the individual compound distribution, phenanthrene is the most abundant PAHs in soil samples. Phenanthrene was also reported to be the most abundant in leachate, river and groundwater close to landfill sites in Ulu Maasop landfill, Kuala Pilah, Negeri Sembilan and Taman Beringin landfill, Selangor [14]. This could be attributed to the fresh input of phenanthrene to landfill through illegal dumping of coal tar. Some of lower molecular weight PAHs, e.g. naphthalene, fluorene and acenaphthene are more volatile and have higher bioavailability compared to phenanthrene and anthracene. Therefore, the lower molecular weight PAHs show low concentrations in the analysed samples. Furthermore, higher molecular weight PAHs, i.e. Benz(a)anthracene, Triphenylene, benzo(j)fluoranthene, Benzo(a)pyrene and BgP: Benzo[ghi]perylene, were found predominant in smaller particles which deposit slowly from the atmosphere.

The presence of phenanthrene and anthracene in high concentrations is an indicator of fresh input of PAHs in soil.

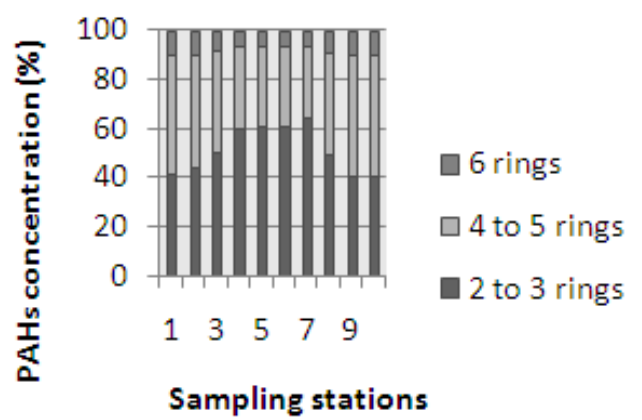

Figure 2. Distribution of PAHs in different sampling locations.

At most sampling stations, 2-3 rings PAHs were predominant, accounting for around $40-65 \%$ to the total PAHs, followed by $4-5$ rings PAHs accounting for $30-50 \%$ and only $6-10 \%$ for 6 rings PAHs as tabulated in Figure 2. The distribution of PAHs was closely similar to the distribution of PAHs found in landfill Tagarades, Greece
[15]. Higher concentrations of 2-3 rings PAHs in soil may be due 2-3 rings PAHs being more hydrophilic than 4-6 rings PAHs, thus 2-3 rings tend to dissolve in water and wet deposition process from atmosphere are higher compare to 4-6 rings PAHs [9].

The maximum value of total PAHs concentration was found to be $329.13 \mu \mathrm{g} / \mathrm{kg}$ much lower than those measured in Tagarades waste landfill, Thessalonik, Greece [15], restored landfill, Hong Kong [2], Kouroupitos waste disposal site, Crete, Greece [16] and Marka landfill, Jordan [17] as shown in Table 6. Highest concentration found at Tagarades waste landfill [15] and Marka landfill [17] was influenced by open combustion and smouldering process. From the investigation of the landfill site, no large open combustion process was found. The landfill had only experienced several small fires in the past, probably due to spontaneous ignition of methane released from mobile flare at $\mathrm{S} 1$.

\subsection{Hazard Assessment on PAHs}

Individual PAHs were compared to two guidelines from Canada and Netherlands [12,10] as shown in Table 7. All PAHs compounds detected were below the permissible concentration limits. Although PAHs level was detected below the guideline limits for residential uses, it is not recommended for housing development especially houses on land surface, e.g. terrace and bungalow. Phenanthrene may contribute health hazard to residents through ingestion of edible plants. Fismes et al.,[18] had reported significant concentrations of PAHs in plant, e.g. potato, lettuce and carrot. In addition, concentration of PAHs in plants can increase with increasing PAHs concentrations in soil. Reference [18] also found higher concentration in lettuce roots compared to leaves. Thus, human ingesting plant from phenanthrene contaminated soil will be exposed to hazards from phenanthrene, e.g. kidney neoplasm and skin irritation.

Table 7. Comparison of Individual PAHs with Guideline ( $\mu \mathrm{g} / \mathrm{kg}$ )

\begin{tabular}{|c|c|c|c|c|c|c|c|c|c|c|c|c|}
\hline PAHs & $\mathrm{Na}$ & Flu & Ac & $\mathbf{P h}$ & An & Fl & Py & $\mathbf{B a A}$ & $\mathbf{T r}$ & $\mathbf{B j F}$ & BaP & BgP \\
\hline MAX & 16.51 & 15.48 & 15.33 & 121.5 & 43.92 & 15.79 & 15.83 & 16.54 & 15.73 & 16.32 & 16.52 & 20.02 \\
\hline Guid $^{\mathrm{a}}$ & 600 & NA & NA & 5000 & NA & NA & 10000 & 1000 & NA & NA & 700 & NA \\
\hline Guid $^{\text {b }}$ & NA & NA & NA & NA & NA & NA & NA & NA & NA & NA & 100 & NA \\
\hline
\end{tabular}

Na: Naphthalene, Flu: Fluorene, Ac: Acenaphthene, Ph: Phenanthrene, An: Anthracene, Fl: Fluoranthene, Py: Pyrene, BaA: Benz(a)anthracene, Tr: Triphenylene, BjF: benzo(j)fluoranthene, BaP: Benzo(a)pyrene, BgP: Benzo[ghi]perylene Guid $^{\text {a }}$ : Guideline from Environment Canada, 2003 for residential uses

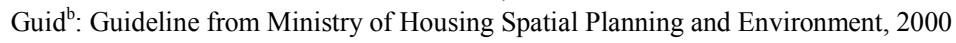

Table 9. Concentration of heavy metals in Kubang Badak landfill(mg/kg)

\begin{tabular}{|c|c|c|c|c|c|c|c|c|c|c|c|}
\hline НМ & As & $\mathbf{P b}$ & $\mathrm{Cu}$ & Mg & $\mathrm{Sr}$ & $\mathrm{Cr}$ & $\mathbf{R b}$ & $\mathbf{G a}$ & $\mathbf{V}$ & Mn & Zn \\
\hline AVE & 7.81 & 26.29 & 38.12 & 58.80 & 71.96 & 89.81 & 98.84 & 115.26 & 105.84 & 121.42 & 406.21 \\
\hline STDEV & 8.97 & 28.56 & 60.17 & 48.58 & 53.88 & 36.15 & 21.57 & 50.86 & 55.18 & 71.74 & 118.52 \\
\hline MIN & 0 & 0.7 & 0 & 16.1 & 0 & 37.8 & 63.7 & 34.3 & 3.85 & 29.05 & 256.9 \\
\hline MAX & 26.9 & 89.25 & 201.6 & 173.6 & 158.2 & 136.85 & 135.8 & 182 & 174.65 & 262.5 & 666.05 \\
\hline
\end{tabular}


However, the Kubang Badak landfill site is suitable for commercial and industrial uses. Human can be exposed to pollutants through air inhalation, dermal absorption and ingestion [19]. Concentrations of phenanthrene detected in this study are acceptable and will not cause health hazards to human through air inhalation and dermal absorption.

Total PAHs concentrations were compared to recommended levels imposed by soil clean-up guidelines from Netherlands and Denmark [10,11] as shown in Table 8. The total PAHs found in this study were below the recommended values and thus, the site is acceptable for human activities. However, the site is not recommended for residential area due to potential of contamination along the food chain as a result of agricultural activities.

Table 8. Comparison of Total PAHs with Soil Clean-up Guidelines

\begin{tabular}{lll}
\hline Country & Sum of 5 PAHs $^{\mathrm{a}}$ & Sum of 10 PAHs $^{\mathbf{b}}$ \\
\hline This study & 32.32 & 250.8 \\
Netherlands & $1500^{\mathrm{a}}$ & \\
Denmark & & $1000^{\mathrm{b}}$ \\
\hline
\end{tabular}

Table 6. Literature data concerning concentrations of PAHs in landfill soils

\begin{tabular}{lcl}
\hline Researchers & $\begin{array}{c}\text { Total PAHs } \\
(\boldsymbol{\mu g} / \mathbf{k g})\end{array}$ & Location \\
\hline This study & $194.59-329.13$ & $\begin{array}{c}\text { closed landfill, Selangor, } \\
\text { Malaysia } \\
\text { operating landfill, Thessaloniki, } \\
\text { Greece }\end{array}$ \\
Ref. [15] & $11.2-1475$ & $\begin{array}{l}\text { restored landfill, Hong Kong } \\
\text { operating landfill, Crete, Greece } \\
\text { closed landfill, Marka Amman, } \\
\text { Ref. [2] }\end{array}$ \\
Ref. [16] & $16-775$ & $\begin{array}{c}\text { operating landfill, Ekeeder/Irbid, } \\
\text { Jordan }\end{array}$ \\
\hline Ref. [17] & $33-3560$ & \\
\hline
\end{tabular}

\subsection{Distribution of Heavy Metals Concentration}

The concentration of heavy metals in soil samples collected within Kubang Badak landfill are shown in Table 9. The highest mean concentration was noted for Zinc (Zn),followed by Manganese (Mn), Gallium (Ga), Vanadium (V), Rubidium (Rb), Chromium (Cr), Barium (Ba), Strontium (Sr), Magnesium (Mg), Copper $(\mathrm{Cu})$, Plumbum $(\mathrm{Pb})$ and Arsenic (As).

Normal concentration range for $\mathrm{Zn}$ in soil is between 1$400 \mathrm{mg} / \mathrm{kg}$ [20]. Zn concentration in soil samples detected in this study is below than $400 \mathrm{mg} / \mathrm{kg}$ except for $\mathrm{S} 1$ $(406 \mathrm{mg} / \mathrm{kg}), \mathrm{S} 5(666.05 \mathrm{mg} / \mathrm{kg}), \mathrm{S} 7(418.25 \mathrm{mg} / \mathrm{kg})$ and S10 $(531.3 \mathrm{mg} / \mathrm{kg})$. The most abundant metal after $\mathrm{Zn}$ was $\mathrm{Mn}$, which varies from 29.05 to $262.5 \mathrm{mg} / \mathrm{kg}$. This is most likely due to the contamination from steel industry nearby which produces scrap iron and used to dispose their waste to the landfill. Same as Mn, V also one of component use steel production speciality in steel alloy. $\mathrm{Cr}$ concentration varies from 37.8 to $136.85 \mathrm{mg} / \mathrm{kg}$. A cement industry located nearby to the landfill site used to dispose their waste from the linings for the rotaries containing $\mathrm{Cr}$. These waste might caused $\mathrm{Cr}$ emissions due to their wear and friction. Normal $\mathrm{Cu}$ concentration range in soil is below $20 \mathrm{mg} / \mathrm{kg}$ [20]. $\mathrm{Cu}$ concentration range in this study was 0 $201.6 \mathrm{mg} / \mathrm{kg}$ and this shows that the investigated area was highly polluted with $\mathrm{Cu}$. $\mathrm{Cu}$ is commonly used as timber preservative in wood industries. During site investigation, wood factory was found close to landfill site and this could be the reason for high concentration of $\mathrm{Cu}$. $\mathrm{Pb}$ concentration range detected in this study was 0.7 $89.25 \mathrm{mg} / \mathrm{kg}$.

Table 10. Literature data concerning concentrations of heavy metals in landfill soils

\begin{tabular}{|c|c|c|c|c|c|c|c|c|c|}
\hline Researchers & Location & $\begin{array}{l}\mathbf{P b} \\
\min \end{array}$ & $\max$ & $\begin{array}{l}\mathrm{Cr} \\
\min \end{array}$ & $\max$ & $\begin{array}{l}\mathbf{C u} \\
\min \end{array}$ & $\max$ & $\begin{array}{l}\mathbf{Z n} \\
\min \end{array}$ & $\max$ \\
\hline This study & Closed landfill, Kubang Badak, Selangor, Malaysia & 0.7 & 89.25 & 37.8 & 136.85 & 0 & 201.6 & 256.9 & 666.05 \\
\hline Ref. [25] & Closed landfill, Likeng village, Guangzhou & 10.1 & 82.7 & 15.8 & 702.6 & NM & & 17.4 & 247.1 \\
\hline Ref. [21] & Sanitary landfill, Sg. Kembong, Selangor, Malaysia & 3.2 & 78 & 4 & 76 & 2 & 326.5 & 12.4 & 128.4 \\
\hline Ref. [24] & Closed unlined landfill, Efkarpia, Thessaloniki & 2.50 & 92.5 & 3.88 & 171.88 & 8.13 & 356.25 & 6.38 & 343.75 \\
\hline Ref. [17] & $\begin{array}{l}\text { Close landfill, Marka Amman, } \\
\text { operating landfill, Ekeeder/Irbid, Jordan }\end{array}$ & 35 & 2380 & 35 & 142 & NM & & NM & \\
\hline Ref. [20] & *Normal concentration in soil & NA & NA & NA & NA & 0 & 20 & 1 & 400 \\
\hline
\end{tabular}

NM: Not Measured

Unit: $\mathrm{mg} / \mathrm{kg}$

Table 11. Comparison of heavy metals ( $\mathrm{mg} / \mathrm{kg}$ ) with CLEA, 2002

\begin{tabular}{lccccccccccc}
\hline HM & As & Pb & Cu & Mg & Sr & Cr & Rb & Ga & V & Mn & \\
\hline MAX & 26.9 & 89.25 & 201.6 & 173.6 & 158.2 & 136.85 & 135.8 & 182 & 174.65 & 262.5 & 666.05 \\
CLEA $^{\mathbf{a}}$ & 20 & 450 & NA & NA & NA & 130 & NA & NA & NA & NA & NA \\
CLEA $^{\mathbf{b}}$ & NA & 750 & NA & NA & NA & 5000 & NA & NA & NA & NA & NA \\
\hline
\end{tabular}


Range of concentrations for $\mathrm{Cr}, \mathrm{Pb}, \mathrm{Zn}$ and $\mathrm{Cu}$ that determined in this study are quite similar reported from other studies as shown in Table 10. Maximum concentrations for $\mathrm{Zn}, \mathrm{Cu}$ and $\mathrm{Cr}$ were detected more than $100 \mathrm{mg} / \mathrm{kg}$ except for study by [21]. Whereas, maximum concentrations for $\mathrm{Pb}$ was detected below than $100 \mathrm{mg} / \mathrm{kg}$ except for study conducted by [17]. These concentrations ranges are very important for bioremediation purpose, as high concentrations of metals can retard degradation of organic contaminant. References [22] reported that high concentrations of $\mathrm{Cu}$ caused an incomplete mineralization of phenanthrene by soil microorganisms. In contrast, low concentrations are essential for the function of certain enzymes in microorganisms for growth, e.g. $\mathrm{Cu}$ and $\mathrm{Zn}$, these are referred as trace elements [23].

\section{Hazard Assessment on Heavy Metals}

$\mathrm{Zn}$ and $\mathrm{Mn}$ concentrations were detected in high concentration in this study. When humans are exposed to high concentration of $\mathrm{Zn}$ and $\mathrm{Mn}$, it will decrease the oxygen level in cells, which $\mathrm{Cu}$ acts as catalyst in formation of hemoglobin [26]. $\mathrm{V}$ is considered toxic by National Institute for Occupational and Health (NIOSH) which cautioned that $35 \mathrm{mg} / \mathrm{m} 3$ can cause permanent health problems or death [27]. Only two sampling stations, i. e. S7 $(136.85 \mathrm{mg} / \mathrm{kg})$ and S8 $(130.2 \mathrm{mg} / \mathrm{kg})$ for $\mathrm{Cr}$ were above $130 \mathrm{mg} / \mathrm{kg}$, which is the concentration limit for residential area. High concentration of $\mathrm{Cr}$ can lead to DNA damage [28]. Acute toxicity for $\mathrm{Cr}$ ranges between 50 to $150 \mu \mathrm{g} / \mathrm{kg}$ High $\mathrm{Cr}$ concentration in human body, can damage liver, kidney and blood cells through oxidations reactions [29]. $\mathrm{Pb}$ concentration range detected in this study was $0.7-$ $89.25 \mathrm{mg} / \mathrm{kg}$. The concentrations are below the stipulated concentrations limit from United Kingdom, thus it shows that the investigate area Kubang Badak landfill is less polluted with $\mathrm{Pb}$. Most sampling station show As is below than $20 \mathrm{mg} / \mathrm{kg}$ except for S7 $(26.95 \mathrm{mg} / \mathrm{kg})$. As a result, the site is not suitable for residential area.

Several heavy metals, i.e. $\mathrm{Cr}$ and As were found to have concentration above concentration limits for residential as shown in Table 11. These metals can be transferred to human body through ingestion from edible plants. Reference [30] has reported positive relationship between leaf and $\mathrm{Zn}$ concentration in soil. All these metals must below than concentration limits by means of remediation process before planning for residential area. Although, the site is not suitable for residential, the site can be used for commercial and industry.

\section{Conclusion}

All the PAHs compounds were distributed uniformly except for phenanthrene and anthracene. Heavy metals on the other hand were not distributed uniformly where $\mathrm{Zn}$ shows high concentrations. Referring to the guideline from
Netherlands, Denmark and Canada [10,11,12] for PAHs, from United States [13] for heavy metals, the landfill area was not suitable for residential area. $\mathrm{Cr}$ and $\mathrm{As}$ are above than concentrations limits for residential uses. These pollutants constitute health hazard to human through ingestion of edible plant. However, the landfill area is suitable for commercial and industry sectors. It is recommended that this preliminary investigation be further developed, to include sampling on nearby river, Sungai Selangor to identify the hazard effect of landfill site to the aquatic environment.

\section{References}

[1] Y.Sumiani, C.C. Onn, M.A. Mohd-Din and W.Z. Jaafar, "Environmental planning strategies for optimum solid waste landfill siting," Sains Malaysiana, 38(4): 457-462, 2009.

[2] M.K. Chung, R. Hu, K.C. Cheung and M.H. Wong, "Pollutants in Hong Kong soils: Polycyclic aromatics hydrocarbons," Chemosphere, 67: 464-473, 2007.

[3] L. Xiaojun, L. Peijun, L. Xin, Z. Chungui, L. Qi, and G. Zongqiang, "Biodegradation of aged Polycyclic Aromatic Hydrocarbon (PAHs) by microbial consortia in soil and slurry phases," Journal of Hazardous Materials, 150: 21-26, 2007.

[4] H.P. Zhao, L. Wang, J.R. Ren, L. Zhuo, M. Li and H.W. Gao, "Isolation and characterization of phenanthenedegrading strains sphingomonas sp. zp1 and tistrella sp. zp5," Journal of Hazardous Materials, 152: 1293-1300, 2007.

[5] L.G. Keith and W.A. Telliard, "Priority pollutants," Environmental Science Technology, 13: 416-423, 1979.

[6] A. Kasassi, P. Rakimbei, A. Karagiannidis, A. Zabaniotou, K. Tsiouvaras, A. Nastic and K. Tzafeiropoulou, "Soil contamination by heavy metals: Measurements from a closed unlined landfill," Bioresource Technology 99: 85788584, 2008.

[7] M. Hazama (private communication). 2010

[8] Star, "Batang Berjuntai folk suffer landfill's stench," Page 6, 2006, May 19.

[9] N.Y.M.J. Omar, M.R. Abas, K.A. Ketuly and N. MohdTahir, "Concentrations of PAHs in atmospheric particles (PM-10) and roadside soil particles collected in Kuala Lumpur, Malaysia," Atmospheric Environment 36: 247-254, 2002.

[10] Ministry of Housing Spatial Planning and Environment, "Circular on target values and intervention values for soil remediation," Ministry of Housing, Spatial Planning and Environment, Netherlands, 2000.

[11] Danish Environmental Protection Agency, "Guidelines on remediation of contaminated sites," Danish Environmental Protection Agency, Denmark, 2002.

[12] Environment Canada, "Canadian soil quality guidelines," Environment Canada, Canada, 2003. 
[13] CLEA, "Contaminated land exposure assessment," R\&D Publication CLR 10, DEFRA and Environment Agency, 2002.

[14] M.P. Zakaria, K.H. Geik, W.Y. Lee and R. Hayet, "Landfill leachate as source of polycyclic aromatic hydrocarbons (PAHs) to Malaysian waters," Coastal Marine 29(2): 116123, 2005.

[15] L. Chrysikou, P. Gemenetzis, A. Kouras, E. Manoli, E. Terzi and C. Samara, "Distribution of persistent organic pollutants, polycyclic aromatic hydrocarbons and trace elements in soil and vegetation following a large scale landfill fire in northern Greece," Environment International 34: $210-225,2008$.

[16] D. Martens, K. Balta-Brouma, R. Brotsack, B. Michalke, P. Scramel, C. Klimm, B. Henkelmann, K. Oxynos, W. Scramm, E. Diamadopoulos and A. Kettrup, "Chemical impact of uncontrolled solid waste combustion to the vicinity of the Kouroupitos ravine, Creete, Greece," Chemosphere, 36: 2855-2866, 1998.

[17] H. Wichmann, M. Kolb, P. Jopke, C. Schmidt, M. Alawi and M. Bahadir, "Assessment of the environmental impact of landfill sites with open combustion located in arid regions by combined chemical and ecotoxicological studies," Chemosphere 65: 1778-1783, 2006.

[18] J.I. Fismes, C. Perrin-Ganier, P. Empereur-Bissonnet and J.L. Morel, "Soil-to-root transfer and translocation of polycyclic aromatic hydrocarbons by vegetables grown on industrial contaminated soils," Journal Environmental Quality 31: 1649-1656, 2002.

[19] M. Mari, M. Nadal, M. Schuhmacher and J.K. Domingo, "Exposure to heavy metal and pcdd/fs by the population living in the vicinity of a hazardous waste landfill in Catalonia, Spain: Health risk assessment," Environment Technology 35: 1034-1039, 2009.

[20] U. Aswatharayana and S.M. Ghandi, "A possible base-metal indicator plant from Mamandur, South India," Journal of Geochemical Exploration 4: 247-250, 1975.

[21] N. Mohamed, U. Hamzah and S. Abd-Rahim, "Heavy metal concentration in soil at Sg. Kembong Landfill, Bangi, Selangor,” Sains Malaysiana, 38 (6): 841-8502009.
[22] J. Sokhn, F.A.A.M. De-Leij, T.D Hart and J.M. Lynch, "Effect of copper on the degradation of phenantherene by soil micro-organisms," Letters in Applied Microbiology, 33: 164-168, 2001.

[23] G.J. Tortora, B.R. Funke and C.L. Case, "Microbiology an introduction," ninth edition, Pearson Benjamin Cummings, 2007.

[24] A. Kasassi, P. Rakimbei, A. Karagiannidis, A .Zabaniotou, K. Tsiouvaras, A. Nastis and K. Tzafeiropoulou, "Soil contamination by heavy metals: Measurements from a closed unlined landfill," Bioresource Technology 99: 85788584, 2008.

[25] W. Xie, D. Chen, H. Zhang, G. Song and X. Chang, "An Investigation into Heavy Metals Pollution in a Landfill of Guangzhou," in $3^{\text {rd }}$ International Conference on Bioinformatics and Biomedical Engineering. Article number 516332. 2009

[26] National Research Council, Food Nutrition Board, "Copper. In: Recommended Dietary Allowances," Washington, D.C. pp. 151-154, 1980.

[27] OSHA (Occupational Safety and Health Administration), "Occupational Safety and Health Guideline for Vanadium Pentoxide," http://www.osha.gov/SLTC/healthguidelines/ vanadiumpentoxidedust/recognition.html, 2009.

[28] D.A. Eastmond, J.T. Macgregor, R.S. Slensinkin, "Trivalent chromium: Assessing the genotoxic risk of an essential trace element and widely used human and animal nutritional supplement," Critical Reviews in Toxicology 38(3): 173190, 2008.

[29] A.D. Dayan and A.J. Paine, "Mechanisms of chromium toxicity, carcinogenicity and allerginicity: Review of the literature from 1985 to 2000," Human and Experimental Toxicology 20(9): 439-451, 2001.

[30] M.J.M. Notten, A.J.P. Oosthoek, J. Rozema and R. Aerts, "Heavy metal concentrations in a soil-plant-snail food chain along a terrestrial soil pollution gradient," Environmental Pollution 138:178-190, 2005. 